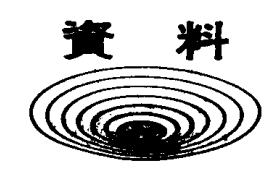

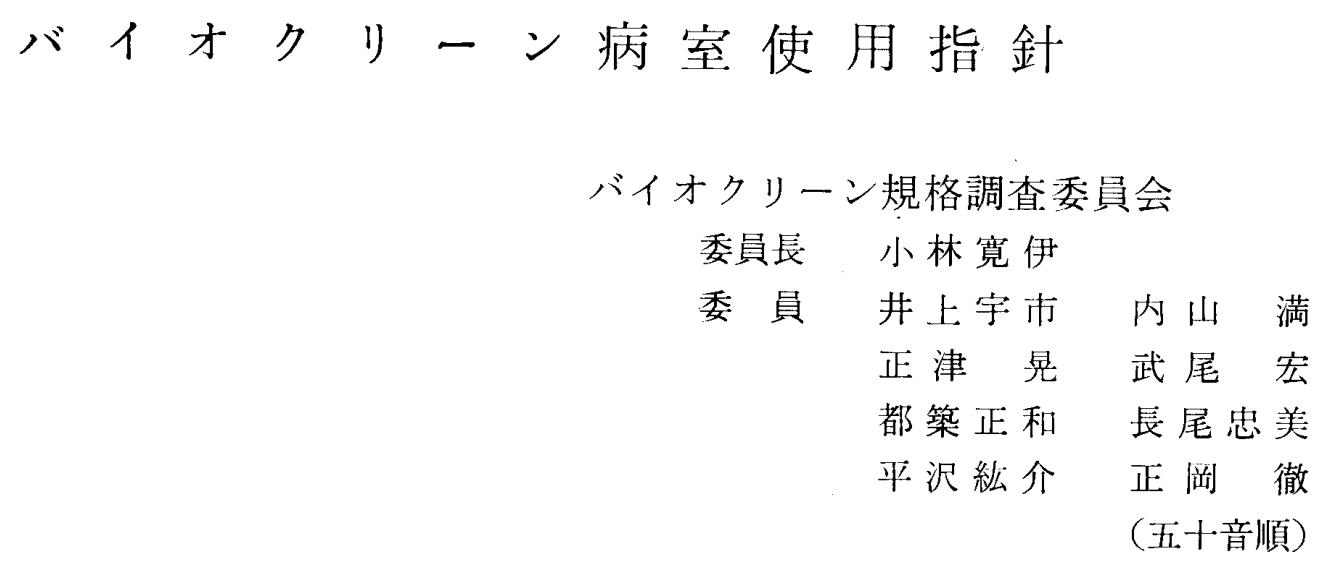

\section{1．適応となる疾患}

バイオクリーン病室が適応となる主な疾患 を以下に示す。

。急性白血病.

。再生不良性貧血（特に骨髄移植を行う 場合).

。顆粒球減少症（薬物副作用, 放射能事 故等).

。免疫不全症候群 (先天性, 後天性).

。臓器移植手術後に強力な免疫抑制療法 在行うとき。

○悪性腫痬に強力な抗腄痬剤を用いると き.

。熱傷の開放療法（今回の指針からは除 外する.)

\section{2. 医師，看護婦の注意事項}

\section{2-1 細菌検查}

鼻且，咽頭の細菌学的検査を定期的に行 うことが望ましい。

\section{2-2 感染症, 創傷}

患者八の感染の危険性を有する感染症ま たは創傷を有する人の入室を禁ずる。

\section{2-3 清潔保持}

身体，頭髪などの清潔保持に心掛ける. しかし入室直前の入浴は避ける(洁1)

\section{2-4 . 下着，ガウン}

下着は下腿露出部の少ないものを着用す る.ガウンは細菌透過性，発じん性の少な いものが望ましく，背面はダブルまたは密 閉形とする。古くなった木綿は不適当で， 不織布または特殊加工された布を用いるべ きである.合成繊維の場合には带電防止対 策を必要とする。

\section{2-5 棺子, マスク}

頭髪，哑を完全に覆う，また皮膚露出面 の少ないものが良い、マスクは細菌沪過効 率の高いものが望ましい。

\section{2-6 履物}

復物による污染物の持ち込みに注意し， 少なくともバイオクリーン病室内外の履物 は区別する。

\section{2-7 手袋}

滅菌した手袋を使用する。手袋の破損 に備え手洗いを十分に行うことが望まし 以(注2)。

\section{2-8 行動}

污染を招来寸るような病室内での行動は 慎む. 行動は必要最小限とする.

\section{3. 入室制限}

面会，見学は面会䖉下または前室で行う。 そのための建築学的配慮が必要である。これ 
ら以外の清潔区域, 準清潔区域に立ち入る場 合には “2 . 医師, 看護婦の注意事項”に従 うこととする。

\section{4. 患者への接近}

バイオクリーン病室の訓練を受けた人のみ に限定する.患者居住域一の立ち入りは最小 限度とし，前室よりアクセスカーテンのグロ ーブを介して处置を行うことを優先すべきで ある、ただし心理学的に問題がある患者に対 しては入室して処置することが必要な場合も ある。

バイオクリーン病室の方式は図 $1,2,3$ の 3 種類があり, 患者への接近方法は以下の 2 つの場合がある.

\section{4-1アクセスカーテンを使用する場合}

アクセスカーテンのグローブ(泳3)を介し て接近寸る.またアクセスカーテンの一部 を開いて処置を行らときには滅菌した帽子， マスク，手袋，上肢のカバーを着用する.

ここから身体をのり出して処置を行うとき には滅菌ガウンを着用する。

\section{4-2 入室する場合}

患者居住域に立ち入る場合には，マスク， 帽子(頭髪を完全に被う形), 背面完全被覆 ガウン，靴カバー，手袋を必ず着用する。 なる心゙く風下のみに立って処置を行う。

\section{5. 患者の処置}

\section{5-1 入室前}

\section{5-1-1 教育}

あらかじめ患者にバイオクリーン病室 の機構, そこにおける治燎の意義, 細菌 污染防止の概念, 入室中の注意事項につ いて十分に教育する．これに協調できる 患者のみをバイオクリーン病室における 治療の対象とすべきである.

\section{5-1-2 一般病室入室中}

バイオクリーン病室入室前 1 週間, 一 般病室に扔いて無菌食, 非吸収性抗生物 質投与(注4)を行うことがある。しかし， その臨床的意義と効果はいまだ確立され ていない。この間, 咽頭, 尿, 粪便, 血
液の細菌検査を適宜行う。

5-1-3 バイオクリーン病室入室直前

頭髪を短めとし，つめを切り，全身の 薬浴(注 5 )を行わせ, 滅菌綿棒で外耳道,

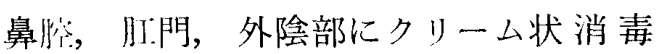
薬(湆6)を塗布する. 滅菌下着を着用させ, 滅菌ガウンで全身を被ってバイオクリー ン病室へ誘導する。

\section{5-2 入室中}

5-2-1 非吸收性抗生物質

入室中は無菌食を与えるが，非吸収性 抗生物質を経口投与する場合が多い(注 4 ). 抗生物質のネブライザーによる吸入また は含嗽を行うこともある(注7)。

5-2-2 細菌検查.

入室中定期的に身体各部，鼻腚，咽頭， 月II門, 皮膚, 尿, 資便, 血液等の細菌検 查を行う。

5-2-3 採血, 注射

(1) アクセスカーテンおよびグローブを 介して行ら場合

必要部品（注射器, 採血管, アンプ ル，駆血帯等）をあらかじめ患者居住 域内に入れて置き，患者自身にこれら をベッドサイドに準備してもらい，患 者の協力を得ながらグローブを介して 採血あるいは注射を行う。検体，使用 済み物品は患者がパスボックスあるい はスイングテーブルに置く . 点滴を行 う場合には点滴セット（エクステンシ ョンチューブ）と翼状針をあらかじめ 患者居住域に入れておく。点滴ボトル は前室側に置く、アクセスカーテンの 点滴セット捙入口のキャップをはずし， 患者にエクステンションチューブの上 流側を前室に出してもらい点滴ボトル に接続する. 次いでグローブを介して 翼状針を接続し点滴を行う。

（2）グローブを介して行わない場合

空より患者の腕を出し, 滅菌覆布上 に乗せて点滴を行う. 通常点滴ボトル は不潔区域に置かれる。 


\section{5-2-4 レントゲン撮影}

open-end 方式（図 1) では患者を室 内に立たせ, 撮影機は前室側において撮 璟する.アクセスカーテンで仕切られた wall to wall 方式（図2）では滅菌済み の袋に入れたフィルムカセットをパスボ ックスより患者居住域内に入れ, 患者は フィルムカセットを撮影部位に保持し, 撮影機は前室側において，アクセスカー テン越しに撮影する。アクセスカーテン のない wall to wall 方式（図3) では, 撮影機を風下に入れて撮影寸る。

\section{5-2-5 心電図検查}

室内立ち入りの5え, 減菌済み電極を 患者に無菌的に装着するが，心電計は室 外に置き，有線または無線で記録する。

有線の場合は滅菌したコードを使用する。 5-2-6 検温, 検脈

污染を持ち込まぬように行う。モニタ 一方式を採用寸るのもよい。

\section{5-2-7 物品の出し入れ}

入室中に必要と予想される物品は入室 前にできるだけ患者居住域内に入れてお くぶきである．人室中に患者居住域へ物 品を出し入れ寸る場合はバイオクリーン 病室の訓練を受けた人のみが行う(注8).

\section{5-3 患者身体の清潔保持}

5-3-1 排泄

排尿，排便後は，局所を清拭し，クリ 一ム状消毒薬(注 6 )を塗布する. 排便後は シャワー浴をさせることもある．患者が おちついて排便，排尿できる環境が望ま しい（例えば用便中ランプ等），排测物 処理には種々の方法がある(注 9 )。

5-3-2 シャワー浴または清拭

全身(頭から足先まで)に消毒洗剂 注:10) を塗りシャワー浴を行わせる. 終了後肘 門部にクリーム状消毒薬(渄6)を塗布する。 シャワー設備のない場合には消毒剤によ る清拭を行う。

\section{5-3-3 手指}

外陰部，鼻孔，耳孔，頭髪，足等に， 不用意に手指が触れないよう指導する。
食事前後，排泄後に消毒剂による手洗い を励行させる。爪は短く切らせる。

5-3-4 歯みがき，含嗽

毎食後歯みがきおよび含嗽を行わせ る(注11).

\section{6. 患者の精神衛生}

\section{6-1 方式}

バイオクリーン病室では，患者が孤独な ため精神衛生上の問題を生じやすい，特に クリーンベンチ方式(図 4)，クリーンブー ス方式 (図 5)，ビニールアイソレータ方 式（図6）では拘束感が強くなるので図 1 〜 3 図の方式が望ましい。

\section{6-2 面会}

面会空を介して随時インターホンまたは 通話空で面会させる．面会空のない場合に は前室まで立ち入りを認めてもよい，幼小 少の場合は十分な訓練のうえ，親を入室さ せる場合もある、その他ゲーム等の配慮が 必要である(注12)。

\section{6-3 新聞, テレビ等}

室内にはテレビ，ラジオ，時計を設置す ることが望ましい，酸化エチレンガス，高 圧蒸気または乾熱処理された手紙，新聞， 雑誌等を持ち込めるよら配慮しなければな らない。

\section{6-4 患者との対話}

䀢療関係者(医師，看護婦，栄養士など) は，バイオクリーン病室患者の訴えを把握 寸るために，多くの対話をもつよう心掛け る.

\section{7. 室内の設備と機器}

\section{7-1 手洗いおよびシャワ一設備}

供給する水または湯は可能な限り無菌化 寸る(注13)。設置位置は気流を考虑する。

\section{7-2 便器}

污染を防止するためにはポータブルの腰 掛け便器で排泄物をビニールパックする方 式が望ましい，水洗方式の場合には，無菌 水は消毒剂添加水道水を用いる.しかし， いずれの方法も便器周囲人の污染を完全に 
医器学 Vol. 52, No. 6 (1982) (31)

は防止できないので，その後処理に留意す

る. 便器は風下に設置する。

\section{7-3 医療用配管}

酸素ガス，真空吸引配管を必要に応じて 設置する、酸素ガス配管の出口に近い所に ラインフィルターを設置することが望まし 以.

\section{7-4 通信設備}

ナースコール，インターホン，電話，テ レビアンテナ端子，モニターテレビなどを 必要に応じて設置する. 室内に便器が置か れている場合, 用便中の表示灯を室外に設 けることが望ましい。

\section{7-5 医療用モニター設備}

検温・検脈端子，聴診器端子，心電図端 子を必要に応じて設置する。

\section{7-6 その他}

読書灯，常夜灯，予備コンセント，空気 中微粒子モニタ一装置，パスボックスまた はスイングテーブル，グローブポートとグ ローブ，ボトルフック，サーモスタット， ヒュミディスタット，その他を環境に灾じ て設備する、スプリンクラーは特殊室であ るため設置しない。また電線管等の開口部 は気密とする。

\section{8. 室内および物品の消毒, 滅菌}

\section{8-1 室内の消毒}

患者入室前に，あらかじめ清掃を十分に 行った上室内の消毒を行う.

\section{8-1-1 薬液散布}

空調を止めたまま消毒薬を散布する (注14).

\section{8-1-2 薬液による清拭}

消毒薬(注15)を浸した減菌布で各部を清 拭，次いで滅菌衣を着用して同様の清拭 をくりかえした後送風を開始する.

8-1-3 ガス消毒(㳸16)

建築の段階において，消毒中のガスも れを子せぐ気密保持に対寸る考慮がはら われていなければならない。また，ガス 消毒のための専用排気系統が設置されて いることも必要である.室内の消毒にあ
たっては，入室中必要な物品をあらかじ め滅菌してできるだけ室内に入れて置き， 減菌したシーツ，葠具によりべッドメー キングを完了しておく．ガス発生後作業 者は速やかに退室し, 粘着テープで出入 口の目張りをする。一定時間放置した後 送風と排気を行う。

\section{8-2 物品の滅菌，消毒と包装}

8-2-1 滅菌, 消毒

患者居住域に持ち込む物は，す心゙て滅 菌，消毒する(湆:17)。

\section{8-2-2 包装}

患者居住域に運び入れれば，それ以上 特別な取り扱いを必要としないもの（文 具，リネン等）は単層包装とし, 患者居 住域内で使われる医療器材（ガーゼ，注 射器など）は二重包装とする. 包装後の 有効期限と污染防止に留意すること.

8-2-3 緊急入室用リネン類

緊急時に備えて，ディスポーザブルの 患者用滅菌下着類などを準備しておくべ きである。

\section{8-2-4 経口薬剂}

経口投与できる注射液がある場合には できるだけそれを利用する，経口薬剤を 投与する場合には清潔に投与する.

\section{8-2-5 給食}

無菌食は原則としてオーブンを用い (注18)，食器をアルミホイルで単層包装し た状態で加熱する，電子レンジによる簡 易法を用いる場合もある。午詰食品，缶 詰またはビン詰のジュースはすべて無菌 食品とみなされ，消毒薬で外側を消毒し て患者居住域に入れてよい，果物では皮 の傷ついていないミカン，スイカ，リン ゴの中味は無菌とみなされる，ただし熟 しすぎたものは注意を要する，表面を消 毒した後，無菌手技のもとに皮をむいて 患者に提供する．イチゴ，モモ，ビワ， ブドウは不可と寸る。

\section{8-3 患者入室中の室内の清潔保持}

8-3-1 ビニールカーテン，グローブ 室内でビニールカーテン，グローブ等 
の破損する可能性があるものを使用して いる場合には，患者が入室するたびにそ の破損の有無を点検しなければならない。 破損に備え常に予備品を用意しておく必 要がある。

\section{8-3-2 無菌水}

無菌水（シャワナ，手洗い用）を使用 している場合には頻回の細菌検査が必要 である.水量が不足したり，菌が検出さ れた場合は専門的点検が必要である.

\section{8-3-3 パスボックス}

毎日, 消毒液による内部清扗が必要で ある。

\section{8-3-4 室内清掃}

セントラルバキュームシステムを用い ることが望ましいが，HEPA フィルタ 一付バキュームクリーナーまたは消毒剤 による清拭(注15)による場合もある。

8-3-5 便器, シャワー設備

患者入室中に，定期的に薬液に上り清 掃をする。

\section{9. 空調設備の運転と保守}

ここで取り扱う空調設備とはバイオクリー ン病室の層流方式を形成させるための装置で, ユニット方式の場合はュニットの運転に関し てのみ言及する。病室にセントラル方式で供 給される空調用空気に対しては病院全体とし ての運転および保守の方針に従わなければな らない。

\section{9-1 空調設備の運転方法}

9-1-1 室内環境の点検

消毒後は入室できなくなるので，消毒 前に簡単な方法によって，層流の風速， 室内の圧力, 温湿度を測定することが望 ましい(泣19)。

9-1-2 風速の切り替え

室内の騒音条件にもとついて層流風速 を変える機構を有する場合は，所定の風 速で使用されているか否かを確認しなけ ればならない。

9-1-3 非常の場合

非常時とは主として停電と火災である。
停電時に非常電源と空調設備が接続され ている場合は問題がない．非常電源がな い密閉式の部屋では人の動きを最小とし て電源の回復を待っ，火災の場合は人命 第一の原則により，できるだけ早く室外 の安全な場所へ誘導する。

9-1-4 運転の停止。

使用後は一般病室に準じた清掃を行い, できるだけ閉鎖した状態に保つ。

\section{9-2 空調設備の保守}

本節の空調設備の保守とは, 病院専属の 保守要員によって行われる事項をいう．以 下の処置は患者入室前に必ず行う。

9-2-1 プレフィルターの点検, 保守

HEPA フィルターの前に設けるプレ フィルターは, 少なくとも月に 1 回程度 の点検をして污染がひどい時は再生また は交換を行う。

\section{9-2-2 風量の調整}

年 2 回以上は HEPA フィルター而の 代表点（1点）で風速を测定し，この風 速が著しく減少した場合はファンベルト のゆるみ，HEPA フィルタのつまりな どの原因を点検してその調整を行い，必 要な場合はサービス技術者に修理を依頼 する。

\section{9-2-3 空調機の保守}

送風機の電流值, 給油状態, ファンベ ルトの点検, 内部の污染状態の点検等は 一般の空調に準じて毎月 1 回以上行う。

\section{9-3 空調設備の保守契約}

層流の清浄度を保つためには，バイオク リーンルームの専門家による点検, 修理が 必要である.このため建設担当会社あるい はバイオクリーン技術に詳しい専門会社と の契約を結び，下記事項について專門のサ 一ビス技術者による年 2 回程度の保守点検 が必要である。

9-3-1 風量の調整

フィルター面上に10点以上の測定点を 選び，風量を正確に測定し，ファンモー ターの回転数またはダンパーの調整が可 能の場合は，これを調整して風量を適正 
值に合致させる。またここ風量が最小 限以下になった場合は, HEPA フィル ターを交換する(注20)

9-3-2 HEPA フィルターのリーク点検

設置後 1 年間は少なくとも年 2 [晶， HEPA フィルターのリークテストを行 うことが望ましく，リークのある場合は パッキンを締め直す(祀21).

9-3-3 清浄度の澌定

室内で重要な点を数点選び，空気中微 粒子数および微生物数を測定する。

9-3-4 室内風速および圧力の測定

熱線形風速計により室内各所の風速を 测定し，とくに層流区域内が適正值に保 たれていることを確認する。

微差压計により室内外の微差圧を測定 し，バイオクリーン病室内が陽圧に保た れていることを確認寸る。

\section{9-3-5 報告書}

サービス技術者は点検保守のたびに上 記の各測定，保守の内容を報告書として 提出子る。

\section{解説}

（注 1）シャワーをかぶることにより皮膚から 発散する空気中細菌が増加するといら報 告がある.

（注２）洗面器内での手洗いは交叉污染の危険 性がある。

（注３）ここでいう手袋とは，手術用ゴム手袋 などを意味し，グローブとはアクセスカ 一テンなどに付属する手袋を意味する。

（注 4）非吸収性抗生物質経口投与の処方例

例 1. polymyxin B $900 \mathrm{mg}$ nystatin 300万箪位

上記 1 日量分 3 投上

例 2. paromomycin $2.25 \mathrm{~g}$ polymyxin $\mathrm{B} \quad 450 \mathrm{mg}$ $150 \%$ 单位

上. 記 1 日量分 3 投与

(注 5) $0.02 \%$ クロールヘキシジン（ヒビテ ン※）液など

(注6) 1\%クロールヘキシジンクリームなど
（注 7） ネブライザーの処方例

例 1. amphotericin B 10mg polymyxin B $\quad 10 \mathrm{mg}$

上記 1 回量 1 日 2 [回]

例 2. amphotericin B $5 \mathrm{mg}$

fradiomycin $\quad 100 \mathrm{mg}$ polymyxin B $5 \mathrm{mg}$ 上記 1 回量 1 日 4 回

（注 8）滅菌手袋を着用した人が，削室におい て搬入物品の外装をとる。 open-end 方 式（図 1）では，物品をスイングテーブ ルに乗せ，これを回転させて搬入する。 アクセスカーテンで仕切られた wall to wall 方式（図2）では，パスボックス を介して搬入する。パスボックスの屝は 雨面同時に開かないようにする。また， パスボックス内部には殺菌灯をつけ，こ れは開屝により消灯するようにする。ア クセスカーテンのない wall to wall 方 式（四 3）では，滅菌衣を着用した人が 風下より搬入する。

（注９）1） ポータブルの腰掛け便器にビニー ル袋をかけ，その中に排泄させる方 法.

2）水洗便所. 使用後は消毒液で洗涤.

3）その他.

（注10）へキサクロロフェン（pHiso $\mathrm{Hex}^{\circledR}$ )， クロールヘキシジンなど

（注11）歯みがきに際しては

1）乾熱滅菌した食塩

2）酸化エチレンガス滅菌した歯みが き粉

3）沪過した水㐘みがき

などを用いる．含嗽水としてはイソジン ガーグル隹 などがある。

（注12）グローブを用いて，トランプ，将棋， その他種々のゲームを行うことができる。

（注13）供給水の処理方法としてはつぎの上う な方法が挙げられる。

1) 熱処理

2) 沪過処理

3）紫外線処理と他の方法との組み合 おせ 
4）消 毒 剂 処 理（無菌化はむずかし (1)

いずれも一長一短を有するが，処理装置 から蛇口までの距離は可能な限り短くし， できれば再循環再処理を常時行い，併せ て蛇口よりの逆行性污染に留意する.

（注14）消毒剤のエアゾールを自動的に噴霧す る方法は，壁，床その他の表面を十分消 毒し得ない危険性があり，近距離から散 布する方法の方が，清拭と同様の効果が 得られる2).

（注15） 1） $0.2 \%$ 過酢酸

2） $0.05 \sim 0.5 \%$ クロールヘキシジン

3) $0.1 \sim 0.5 \%$ 次亜塩素酸ソーダ （手袋着用のこと）

4） $2 \%$ グルタールアルデヒド（手袋 着用のこと，気道刺激性強し）

5）その他

（注16） ホルムアルデヒドガス消毒3），オゾン 消毒"゙などがあげられる。

ホルムアルデヒドガス消毒の例 ${ }^{32}$

1）部屋の容積を計算する。

2）容積に従ってホルムアルデヒドガ ス発生器にホルマリン水を入れる. ホルマリン $15 \mathrm{~m} l$ (ホルムアルデヒ ド $6 \mathrm{~g}) / \mathrm{m}^{3}$

水 $40 \mathrm{~m} l / \mathrm{m}^{3}$

3）空調をとめる.

4）部屋の目張りを行う.

5）ホルムアルデヒドガス発生器の電 源を入れる。

6） 7 時間後に排気と共に空調を開始 寸る。

（注17）1）高圧蒸気

2）酸化エチレンガス

3）沪過

4) 乾熱

5) 放射線

6） ホルムアルデヒドガス

7） その他
（注18） $250^{\circ} \mathrm{C} \quad 20$ 分 $200^{\circ} \mathrm{C} 30$ 分

（注19）医師または看護婦が行う簡易測定法と しては次の方法が良いと思われる。

1）風速は HEPA フィルターの前面に 細糸を取り付けて，これが気流とな寸 角度，またはタバコの煙の速度等によ り判断する.

2）室内の圧力は，すきま部よりの空気 の流れる方向，またはビニールシート 等のふくらみ方向により判断する.

（注20） HEPA フィルターの寿命をフィルタ 一前後の差圧により判断することがある が，差圧のみで判断するとファンの特性 によっては，吹き出し風量が著しく減少 していることがある・このためバイオク リーンルームの HEPA フィルターの寿 命についてはあくまで風量すなわち風速 を基準として判断し，これが適正值以下 になった場合は交換しなくてはならない。

（注21） HEPAフィルターは取り付け後 $6 \sim 12$ カ月の間はパッキンの老化あるいは振動 によるゆるみが生じることが多いので, とくにこの期間にリークテストが必要に なる. HEPA フィルターのリークテス トは HEPA フィルターの上流で DOP のエヤーゾールを発生するか，大気塵を 用いて，フィルターの下流において測定 する。

\section{文 献}

1) Speers, R. Jr.: Increased dispersal of skin bacteria into the air after baths, Lancet, i : $478 \sim 480,1965$.

2) Spaulding, E. H : Chemical disinfection and antisepsis in the hospital, J. Hosp, Res., 9 : $7 \sim 31,1972$.

3）垃星忠美 : 病院施設の消毒—BC 施設への適 用, 医器学, 49:302 307, 1979.

4) Masaoka, T. et al: Ozone decontamination of bioclean rooms, Appl. Environ. Microbiol. $43: 509-513,1982$ 


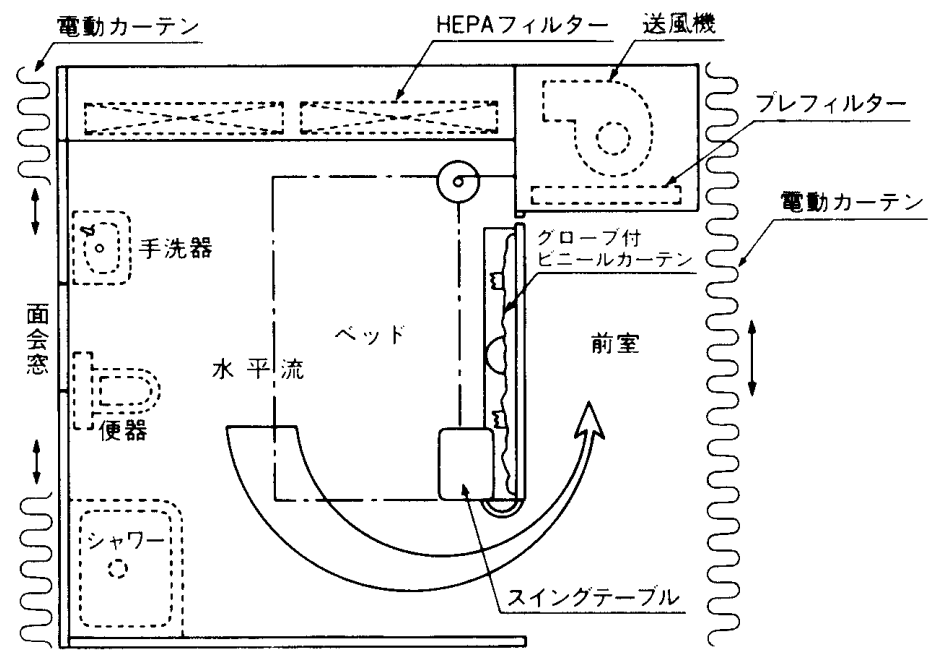

图 1 水平要流 open-end 方式

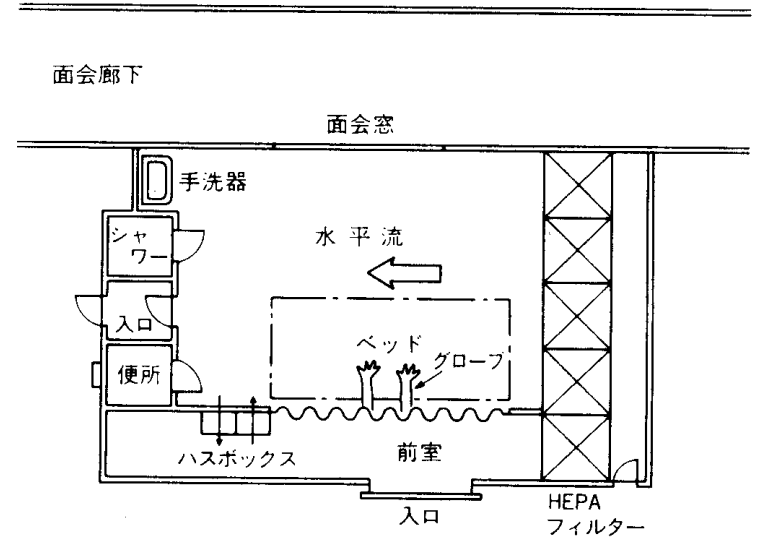

图 2 水平雷流 wall to wall 方式, アクセスカーテンつき

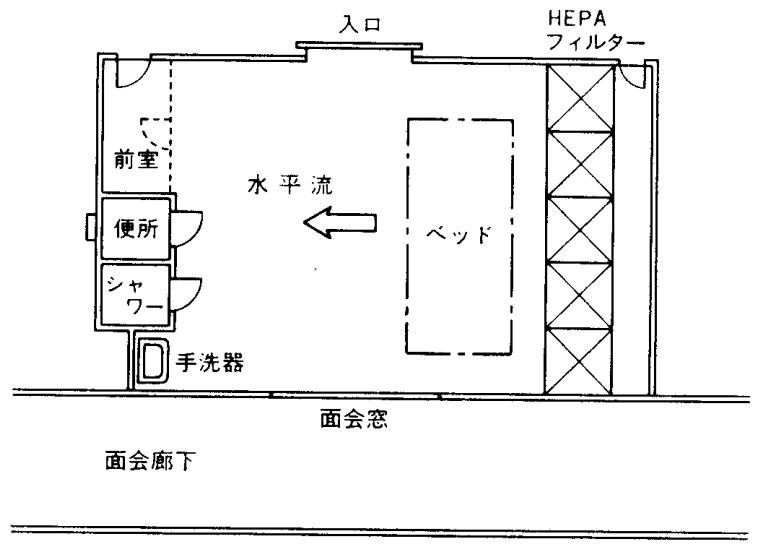

图 3 水平届流 wall to wall 方式, アクセスカーテンなし
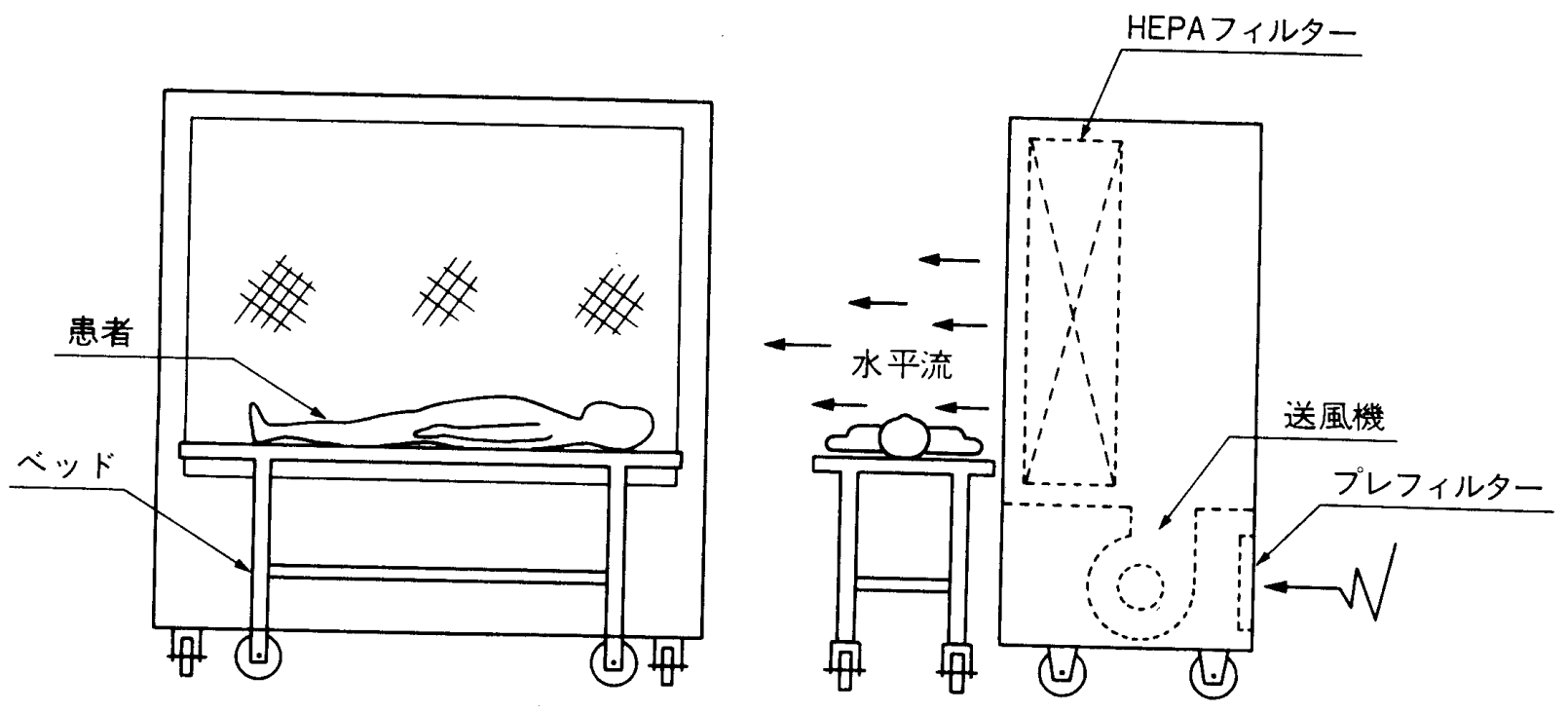

图4 クリーンベンチ方式 
(36) 医器学 Vol. 52, No. 6 (1982)

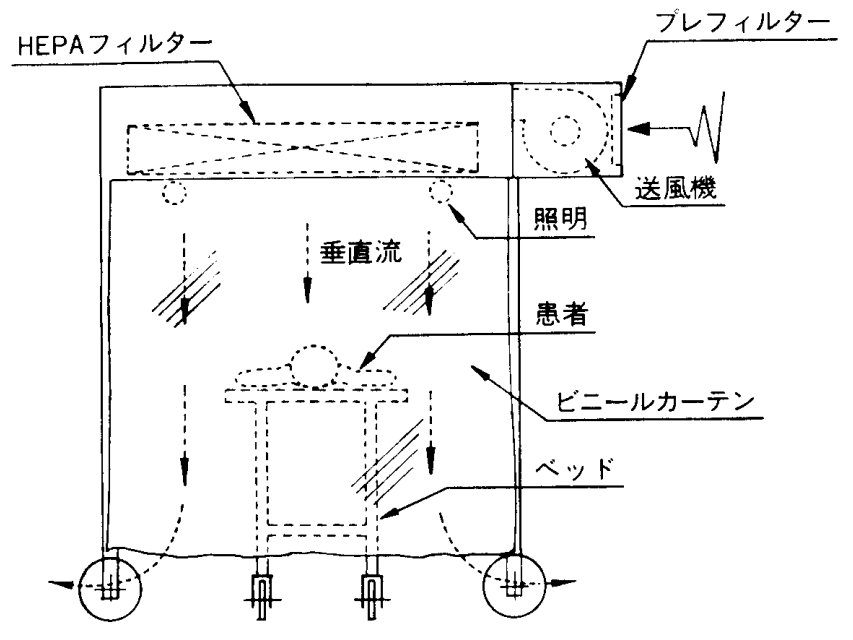

図 5 クリーンブース方式

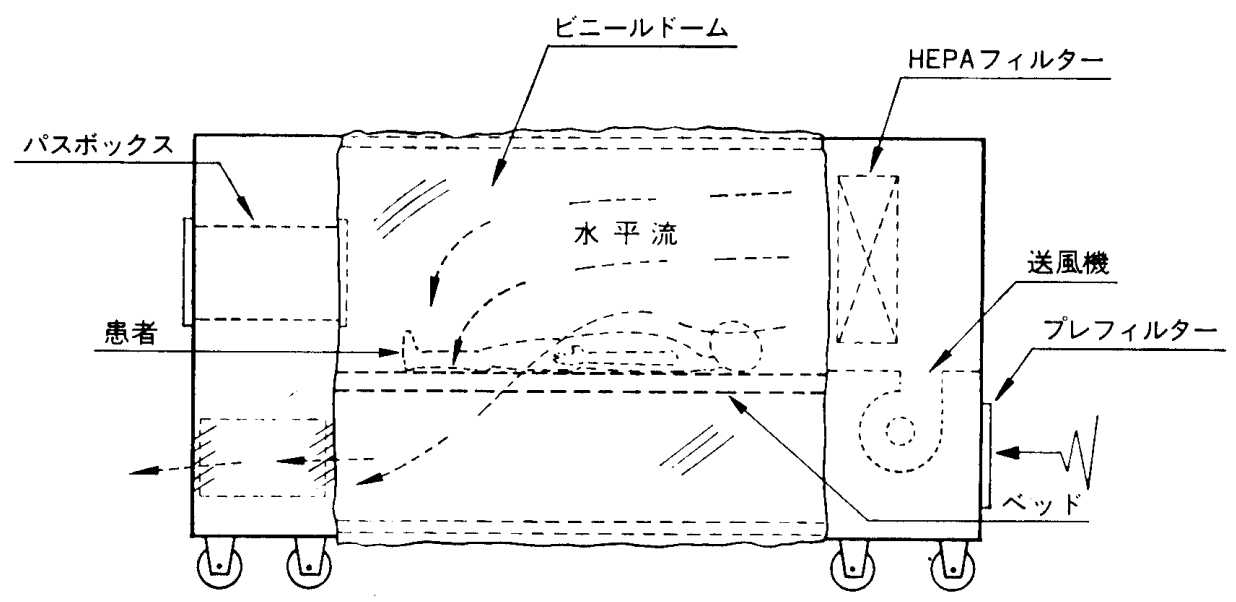

図 6 ビニールアイソレーター方式 


\title{
GUIDELINE FOR THE USAGE OF BIOCLEAN PATIENT ROOMS
}

\author{
MISJ
}

Standard Committee on Bioclean Rooms in Hospital

CHAIRMAN: Hiroyoshi Kobayashi, M.D.

MEMBERS: Uichi Inouye, Ph D., Mitsuru Uchiyama, Akira Shotsu, M.D.. Hiroshi Takeo, M.D., Masakazu Tsuzuki, M.D., Tadami Nagao, M.D., Kosuke Hirasawa, Tohru Masaoka, M.D.

\section{INDICATIONS}

Main indications for Bioclean Patient Rooms (BCPR).

* Leukemia

* Aplastic anemia (particularly when the marrow transplantation is needed).

* Granulocy topenia (side-effects of drugs, radioaccident and other causes).

*Immunodeficiency syndrome (congentital and acquired).

*When an intensive immuno-suppressive therapy is performed after the surgery of transplantation.

* When an intensive chemotherapy is employed against malignant tumor.

* Open therapy of burn (excluded from this guide line).

\section{PATIENT CARE TEAM (Doctor, Nurse)}

\section{2-1. Bacteriological Test}

Periodical bacteriological examination of the nasopharyngeal area is recommended.

2-2. Infectious disease and wound

Those who have infectious diseases or wounds and may have any risk of spreading an infection to the patient should not be allowed into the BCPR.

2-3. Cleanliness of the body, etc.

Body, hair, etc. should be kept clean. However, bathing just before coming in to the BCPR should be avoided. (Note 1)

2-4. Underwear and gown

Legs of all members of the BCPR patient care team should be covered as much as possible by appropriate underwears. Material with little bacterial penetration and particulate shedding or linting characteristics should be used for gowns. The gown should be so designed that the back part overlaps completely or be of closed type. Old cotton material should never be used. Gowns made of appropriate non-woven fabrics or specially treated woven fabrics should be used. In case a synthetic fiber material be used, due measures should be taken to control the static electricity.

2-5. Cap and mask

Hair and beard should be fully covered. Skin surface should be covered as much as possible by cap and mask. Mask with good ventilation and high bacterial filtration are preferred.

\section{2-6. Footwear}

Caution should be taken to prevent contamination of the BCPR by the footwear of team members. Separate footwear should be prepared for use in the BCPR.

2-7. Rubber glove

Sterile rubber gloves should be used. Good hand-washing practice should be performed in order to be prepared for a possible breakage in the gloves. ${ }^{\text {(Note 2) }}$ 


\section{2-8. Movement}

Such movement as to cause contamination in the BCPR should be avoided. Personal movement within the BCPR during the care of the patient must be kept to an essential minimum.

\section{CONTROL OF THE VISITORS}

Visit should be made from the visitors' corridor or in the ante-room. Due attention should be paid by the architect in designing the BCPR facilities. In case a visitor will have to come to the clean and/or sub-clan areas, the visitor must follow the guideline as shown in Section 2, "Patient Care Team (Doctor, Nurse)".

\section{ACCESS TO THE PATIENT}

The access to the patient should be limited to persons who have been trained for BCPR. The patient should be treated in the ante-room through the gloves attached to the access curtain to keep a minimum entrance into the BCPR. It may be necessary for the patient with psycologic problems to enter the BCPR for treatment.

There are three systems of BCPR as shown in Figs. 1, 2 and 3, and the access to the patient is gained in the following two ways:

4-1. The use of the access curtain

The access to the patient should be gained through the gloves attached to the access curtain. When a part of the access curtain is opened for treatment, sterile cap, mask, surgical rubber gloves and cover for arms should be used. To lean into the curtain, a sterile gown should be used.

4-2. Entrance into the bioclean patient room

To enter the BCPR, mask, cap (one which covers the entire hair), gown covering the back completely, cover for shoes and surgical rubber gloves should be used. Patient care team shall stand on the lee.

\section{MANAGEMENT OF THE PATIENT}

\section{5-1. Before the patient enters the BCPR}

\section{5-1-1. Patient education}

The patient should be educated about the structure of the BCPR, significance of treatment in the room, concept of prevention of bacterial contamination, rules for use of the room before entering the room. Only patients who can understand and cooperate them should be selected for the BCPR therapy.

5-1-2. In the general ward

The patient may be given sterilized food and non-absorbable antibiotics in the general ward one week before he is transfered to the BCPR (Note 3) However, their clinical significance and effects have not yet been established. Bacteriological examinations of pharynx, urine, feces and blood shall be made where necessary.

\section{5-1-3. Just before the patient enters the BCPR}

The patient should be hair cut, do his nails, and take a medicated bath. (Note 4) Creamy disinfectant should be applied to the external auditory meatus, nasal cavity, anus and perineal area with an applicator. (Note 5) The patient should use sterile underware and gown and guided to the BCPR.

\section{5-2. In the BCPR}

\section{5-2-1. Non-absorbable antibiotics}

The patient should be given sterile food in the BCPR. Non-absorbable antibiotics are often orally administered to the patient. (Note 3) The inhalation of non-absorbable antibiotics through a nebulizer or gargling with it is occasionally performed. (Note 6 )

\section{5-2-2. Microbiological examinations}

Periodical microbiological examinations should be made on various parts of the patient's body, nasal cavity, pharinx, anus, skin, urine, feces, blood and others.

\section{5-2-3. Blood samples and injections}

(1) When these procedures are made through the access curtain and gloves

Necessary supplies (for example, syringe, blood sample tube, ampule) should be placed in the BCPR beforehand. The patient shall be asked to arrange them 
at his bedside for blood samples or injection through the gloves in cooperation with the patient. The patient shall place test specimens and used supplies in the pass box or on the swing table. When infusion is made, a drip set (extension tube) and needle should be placed in the BCPR beforehand. Drip bottles should be placed in the ante-room. The cap shall be removed from the orifice of the access curtain which accepts the drip set, and the patient shall be asked to put the proximal top of the extension tube out of the orifice to connect it to the drip bottle. The needle shall be connected to the extension tube through the gloves for infusion.

(2) When the glove is not used

The patient should be asked to put his arm out of the window and place it on the sterile cloth for infusion. Usually, the drip bottle should be placed in the unclean area.

\section{5-2-4. Radiography}

In the open-end system (Fig. 1), the patient shall stand in the BCPR and the radiographic unit should be placed on the lee. In the wall to wall system with the access curtain (Fig. 2), a film cassette contained in a sterile bag shall be placed in the patient's living area through the pass box, the patient shall hold the film cassette in the site being radiographed, and the radiographic unit should be placed in the the ante-room for radiogram through the access curtain. In the wall to wall system without the access curtain (Fig. 3), the radiographic unit should be placed on the lee.

\section{5-2-5. Electrocardiography}

The operator will enter the BCPR to place the sterile electrodes aseptically on the patient in position. The electrocardiograph should be placed outside the room and record by a wire or wireless. When a wire is used, a sterile cord should be employed.

5-2-6. Measurement of body temperature and pulse

The BCPR must be kept from contamination during measurement of body temperature and pulse. The use of a monitor is recommended.

5-2-7. Taking commodities in and out

Commodities which are expected to be necessary during the patient's stay in the BCPR should be placed in the patient's living area beforehand. Only persons who have been trained for BCPR are allowed to take commodities in and out of the room. ${ }^{\text {Note } 7)}$

5-3. Keeping cleanliness of the patient's body

\section{5-3-1. Excretion}

After urination and defecation, the site should be cleaned and a creamy disinfectant should be applied to the site. (Notes) The patient may have a shower after defecation. It is desirable to create an environment under which the patient can restfully defecate and urinate (for example, use of a lamp telling that the toilet is occupied). There are several methods for discarding excretion. ${ }^{(\text {Note }}{ }^{8)}$

\section{5-3-2. Having a shower or cleansing}

A disinfectant (Note9) should be applied to the whole body of the patient (from head to toes) to have a shower. After having a shower, a creamy disinfectant (Notes should be applied to the anal region. When the bioclean room has no shower, the patient should be cleansed with a disinfectant.

\section{5-3-3. Fingers}

The patient should be instructed not to touch carelessly the external genital area, naris, auditory meatus, hair, feet and other parts. He also should be instructed to make it a rule to wash his hands before and after meal and after relieving nature and do his nails.

\section{5-3-4. Tooth-brushing and gargling}

The patient should be instructed to brush his teeth and have a rinse after every meal. (Note 10)

\section{MENTAL HYGIENE OF THE PATIENT}

The patient often has problems associated with mental hygiene in the BCPR as he is lonely. 


\section{6-1. System of BCPR}

The systems shown in Figs. 1 to 3 are recommended, since the clean bench system (Fig. 4), clean booth system (Fig. 5) and plastic isolator system (Fig. 6) increase the patient's feeling of restraint.

\section{6-2. Interview}

Visitors should have an interview with the patient through the interview window by mean of an interphone or a conversation window. When the BCPR has no interview window, visitors may be admitted to enter the ante-room. In case of infants and small children, parent may be occasionally admitted to enter the BCPR after sufficient training. Games should be provided for children. (Note 11)

6-3. Newspaper, television set and other amusements

It is desirable to place television set, radio and clock in the BCPR. Care must be taken so that the patient can bring letters, newspapers, magazins and other amusements treated with ethylene oxide gas, saturated steam or dry-heat sterilization procedure into the room.

6-4. Dialogue with the patient

The medical personnel (doctor, nurse, dietitian and other members) should try to have chances of dialogue with the patient in the BCPR as many as possible to grasp his complaints.

\section{FACILITIES AND EQUIPMENT IN THE BCPR}

7-1. Hand-washing and shower facilities

Water or hot water to be supplied should be free from the organisms to the possible degree. (Note 12) The direction of the air flow should be considered in decision of location of these facilities.

7-2. Stool

A western-style portable stool which packs excretion in a plastic bag is recommended to prevent contamination. In a flush system, tap water containing a disinfectant should be used. The stool should be carefully treated after use, as neither system can completely prevent contamination around the stool. The stool should be installed on the lee.

7-3. Plumbing for medical gases

Lines for oxygen gas and vacuum aspiration shall be laid where necessary. It is advisable to place a line filter near the outlet of the oxygen gas line.

7-4. Facilities for communication

Nurse call, interphone, telephone, the television aerial terminal and monitor television shall be set up where necessary. It is desirable to place a pilot lamp outside the BCPR which tells that the toilet is occupied.

7-5. Facilities for medical monitors

Terminals for measurement of body temperature and pulse, stethoscope and electrocardiography shall be furnished where necessary.

7-6. Others

Reading light, all-night light, spare outlet, device to monitor particles in the air, pass box or swing table, glove port, gloves, bottle hook, thermostat, humidistat and other facilities shall be furnished according to the environment. No sprinkler head shall be equipped as the $\mathrm{BCPR}$ is a special room. The orifice of the electric cord tube shall be air-tight.

\section{DISINFECTION AND STERILIZATION OF THE BCPR AND COMMODITIES}

8-1. The BCPR should be completely cleansed and disinfected before the patient uses it.

\section{8-1-1. Disinfection of the BCPR}

A disinfectant should be sprayed with the air-conditioner in the off position! Nute 131

8-1-2. Hand-wipe with disinfectant

Various parts of the BCPR should be wiped with a sterile cloth immersed with a disinfectant. (Note 14) After repeated wiping with sterilized gown, ventilation should be started.

8-1-3. Gaseous disinfection (Note 15)

Measures must be taken under construction of the BCPR to maintain air-tightness to prevent gas leakage during disinfection. A special exhaust line must be laid on 
for gaseous disinfection. Before disinfection of the BCPR, necessary and sterile commodities should be put in the room as many as possible and sterile sheet and bedcloths should be used to complete bed-making. The workers should readily leave the room after gas generation and seal the door way with an adhesive tape. The room should be left for fixed hours before ventilation and exhausion.

8-2. Sterilization and disinfection and wrapping of commodities

8-2-1. Sterilization and disinfection

All commodities which are brought in the patient's living area should be sterilized and disinfected. (Note 16)

8-2-2. Wrapping

Once commodities are carried in the patient's living area, those which require no further special handling (writing materials, linens, etc.) shall be wrapped in a single layer, and medical instruments and materials (gause, syringe, etc.) which are used in the patient's living area should be double wrapped. Special attention should be paid to the shelf life and prevention of contamination after wrapping.

8-2-3. Preparation of linens for emergent admission

Disposable and sterilized underwears for the patient should be provided against emergency.

8-2-4. Oral drugs

Injections which allow oral administration should be used as many as possible, if available. Such drugs shall be cleanly administered.

8-2-5. Meals

In principle, an oven (Note ${ }^{17)}$ should be used to the aseptic food with the dish being wrapped with a sheet of alminium foil. A simple method by means of an electronic oven may be used. Canned food, canned or bottled juice are all regarded as aseptic and can be brought in the patient's living area after disinfection of the outer surface of these cans and bottles with a disinfectant. The contents of oranges, water-melons and apples which have intact rinds are regarded as aseptic. Precautions must be used against overripe fruits. The rind should be disinfected and peeled asepticaly to provide it with the patient. Strowberries, peaches, Japanese medlars and grapes should be forbidden.

8-3. Keeping cleanliness of the BCPR in use

8-3-1. P.V.C. curtain and gloves

When P.V.C. curtain and gloves which are likely to be torn are used, the presence of tear in them should be checked between patients.

8-3-2. Aseptic water

Frequent microbiological examinations must be made when aseptic water (for shower and toilet) is used. When water run short or bacteria are detected in the water, a technical inspection must be called for.

8-3-3. Pass box

The pass box should be daily cleansed with a disinfectant on the inside.

8-3-4. Cleaning of the BCPR

It is desirable to use a central vacuum system. A vacuum cleaner with a HEPA filter or a disinfectant may be utilized.

8-3-5. Toilet and shower facilities

Toilet and shower facilities should be periodically cleansed with a disinfectant while the patient is in the BCPR.

\section{OPERATION AND MAINTENANCE OF THE LAMINAR AIR FLOW (LAF) UNIT}

The "LAF unit" dealt with in this section refers to a equipment for generating laminar air flow in the BCPR. For the unit system this section refers to only the operation of the unit. The operation and maintenance of the air-conditioning through the central system must follow the policy of the hospital.

9-1. Operation of the LAF unit

9-1-1. Inspection of the condition of the BCPR

It is recommended to determine the velocity of the laminar air flow, pressure, 
temperature and humidity in the BCPR by a simple method prior to disinfection, as nobody is allowed to enter the room after disinfection. (Note 18)

9-1-2. Adjustment of velocity

When the LAF unit has a mechanism for adjusting the velocity of laminar air flow based on the noise in the BCPR, check to see that the LAF unit is used at the desired velocity.

9-1-3. Emergency

Emergency mainly represents power failure and fire. There will be no problems occurring in emergency if the LAF unit is connected to the emergency power. In the closed room with no emergency power, the movement of people should be minimized until the power is recovered. In fire the patient should be guided out the BCPR to the safety place as soon as possible according to the rule of life first.

9-1-4. Switching off the LAF unit

After use, the BCPR should be cleansed according to the cleaning procedures for the general ward and kept sealed as tightly as possible.

\section{9-2. Maintenance of LAF unit}

The general maintenance of the LAF unit as described here should be the responsibility of the hospital engineer. Following should be done before the patient is admitted to the BCPR.

\section{9-2-1. Checking and maintenance of pre-filter}

The pre-filter which is placed before the HEPA filter should be checked at least once a month, and cleaned or replaced as appropriate if there is visible evidence of clogging of the filter opening.

\section{9-2-2. Adjustment of air flow volume}

At least two or more times per year, air velocity should be measured near certain surface points on the HEPA filter. If the velocity is below specifications, it should be increased to the normal operating range by adjusting the blower output using the blower motor speed control or changing the drive belt pulley ratios as provided in the equipment design. If after maximum adjustment, the velocity is still below specification, it is probably necessary to replace the HEPA filter. To be done properly, these checks and adjustments or replacements may require the services of the manufacturer's service engineer.

\section{9-2-3. General maintenance of LAF unit}

Such preventative maintenance procedures as checking of the electrical current draw of the blower units, bearing grease cup, fan belt condition, removal of dust inside blower housing, etc. should be performed every month or more often just as in the case of the ordinary air conditioning units.

\section{9-3. Preventative Maintenance of the LAF Unit by a Service Engineer}

In order to maintain the effectiveness of the laminar air flow, periodic checking and repair by a specialist in LAF is essential. Therefore, it is advisable to make a contract either with the company which supplied the BCPR, or a company specializing in LAF preventative maintenance services for a bi-annual inspection for the following:

\section{9-3-1. Measurement and adjustment of air flow volume}

Using a sensitive thermo-anemometer air flow meter, get an accurate average measurement of the air velocity by selecting more than ten points on the HEPA filter. If necessary, air velocity should be adjusted to the appropriate level by changing the rotation speed of the fan motor or the blower or by adjustment of flow dampers. When the velocity goes down to lower than the minimum acceptable levels, the HEPA filter should be replaced. (Note 19)

\section{9-3-2. Checking for leaks from the HEPA filter}

During the first year after the installation, leak tests of the HEPA filter should preferably be done twice. Leaks at the gasket seal or in the filter media should be corrected or repaired as appropriate to eliminate the leakage. (Note 20 )

\section{9-3-3. Measurement of the air cleanliness}

Select several critical points in the BCPR to measure the number of air-borne particles and bacteria. 
9-3-4. Measurement of the air velocity and the air pressure in the BCPR

Check the air velocity at several points in the BCPR by thermo-anemometer velocity meter and confirm that the velocity in the laminar air flow is kept within the appropriate range.

Using a precise pressure meter, check the pressure differential between inside and outside of the BCPR. The pressure inside the BCPR area must always be kept at a slightly higher pressure as compared to adjacent outside areas.

\section{9-3-5. Reporting}

After each service call, the service engineer should submit a report on the results of the above measurements and related service activities.

\section{Note Commentary}

(Note 1) It has been reported that an increasing number of bacteria are emitted from the skin in the air after having a shower."

(Note 2) Hand-washing in a basin may have a cross-contamination.

(Note 3) Formulas of non-absorbable antibiotics by oral route

$\begin{array}{lll}\text { Ex. 1. Polymyxin B } & 300 \mathrm{mg} \\ & \begin{array}{l}\text { Nystatin } \\ 3 \text { times daily }\end{array} & 1,000,000 \text { units } \\ & \\ \text { Ex. 2. Paromomycin } & 750 \mathrm{mg} \\ & \begin{array}{l}\text { Polymyxin B } \\ \text { Nystatin }\end{array} & 150 \mathrm{mg} \\ & 3 \text { times daily } & 500,000 \text { units }\end{array}$

(Note 4) $0.02 \%$ chlorhexidine solution and similar type of agents

(Note 5) 1\% chlorhexidine cream and similar type of agents

(Note 6) Formulas of nebulizer

$$
\begin{aligned}
& \text { Ex. 1. Amphotericin B } 10 \mathrm{mg} \\
& \text { Polymyxin B } \quad 10 \mathrm{mg} \\
& \text { twice daily }
\end{aligned}
$$
Ex. 2. Amphotericin B $5 \mathrm{mg}$

Fradiomycin $\quad 100 \mathrm{mg}$
Polymyxin B $\quad 5 \mathrm{mg}$

4 times daily

(Note 7) The person who wears sterile surgical rubber gloves shall take charge of carrying commodities from the ante-room to the patient's living area. In the open-end system (Fig. 1), the commodities should be placed on the swing table which is turned round to carry in the area. In the wall to wall system with the access curtain (Fig. 2), this should be done via the pass box. The door of the pass box should be so designed that both sides will not simultaneously open. The pass box should have a bactericidal ultraviolet lamp in the inside which is put off by openning the door. In the wall to wall system without the access curtain (Fig. 3), the person who wears a sterilized cloth should carry commodities from the lee to the patient's living area.

(Note 8) (1) A plastic bag is placed in the western style portable stool and the patient eases nature in the bag.

(2) Flush toilet. After use, the stool shall be washed with a disinfectant.

(3) Others

(Note 9) Hexachlorphene, chlorhexidine and similar type of agents

(Note 10) The following tooth pastes are used:

1. Dry-sterilized salt

2. Tooth paste sterilized with ethlene oxide gas

3. Filtered water

Gargles recommended include povidone-iodine. 
(Note 11) Cards, chess and other various games can be played through the gloves attached to the access curtain.

(Note 12) There are the following methods for treating water supplied:

1. Heat treatment

2. Filtering

3. Combination of an ultraviolet ray and other methods

4. Cold treatment with disinfectants (it is difficult to achieve asepsis).

Any of these methods has advantages and disadvantages. The distance between the treatment device and the tap should be as short as possible. Whenever possible, treatment and circulation should be repeated. Care must be taken against retrograde contamination from the tap.

(Note 13) An automatic fogging of a disinfectant may not achieve sterilizing effects to the sufficient dgree. Spray from the shorter distance is recommended as it has equal sterilizing effects to hand-wipe with a cloth immersed with a disinfectant. ${ }^{21}$

(Note 14) 1. $0.2 \%$ peracetic acid

2. $\quad 0.05-0.5 \%$ cholrhexidine

3. $\quad 0.1-0.5 \%$ sodium hypochlorite (Surgical rubber gloves must be used.)

4. $2 \%$ glutaraldehyde (Surgical rubber gloves must be used. It has strong irritation to the air-way.)

5. Others

(Note 15) Disinfections by formaldehyde ${ }^{3)}$ and ozone ${ }^{4)}$ are included.

Disinfection by formaldehyde ${ }^{3)}$

(1) Calculate the volume of the room.

(2) Place an appropriate volume of formalin water in the formaldehyde gas generator based on the calculated volume of the room.

$$
\begin{aligned}
& 15 \mathrm{ml} \text { of formalin }(6 \mathrm{~g} \text { of formaldehyde }) / \mathrm{m}^{3} \\
& 40 \mathrm{ml} \text { of water } / \mathrm{m}^{3}
\end{aligned}
$$

(3) Turn off the air-conditioner.

(4) Seal the room with an adhesive tape.

(5) Switch on the formaldehyde gas generator.

(6) Start exhaustion and air-conditioning 7 hours later.

(Note 16) (1) Saturated steam

(2) Ethylene oxide gas

(3) Filtering

(4) Dry-heat

(5) Radiation

(6) Formaldehyde gas

(7) Others

$\begin{array}{lll}\text { (Note } 17) \quad 250^{\circ} \mathrm{C} & 20 \text { minutes } \\ 200^{\circ} \mathrm{C} & 30 \text { minutes }\end{array}$

(Note 18) The following simple methods are recommended for doctors and nurses:

(1) The velocity of the laminar air flow is judged on the basis of the angle between a fine string in front of the HEPA filter and the air flow or the velocity at which the smoke of cigarette trails.

(2) The pressure in the room is assayed based on the direction to which air flows through the small opening in the door or the direction to which a plastic sheet gets inflated.

(Note 19) There are some installations where the life of HEPA filters has been checked by the pressure drop through the HEPA filters. However, the low air volume may be because of the performance of the fan. Therefore, the life of the HEPA filter should always be judged on the air flow. When the air flow velocity goes down below a pre-set appropriate figure and can no longer be adjusted upward, the HEPA filter should be replaced. 
(Note 20) It is possible that in the first 6 to 12 months, leaks may appear at the HEPA filter because the filter gasket seal has taken a set or vibration has loosened the hold-down clamps.

Checks for leakage of the HEPA installations should be made using a DOP aerosol or air lint introduced on the upstream side of the HEPA filter. The penetration is measured on the downstream side of the filter.

(Translated by Kenji Hirata, Tohru Masaoka, M.D. and Hiroyoshi Kobayashi, M.D.)

\section{REFERENCES}

1) Speers, R.Jr.: Increased dispersal of skin bacteria into the air after baths, Lancet, i: $478-480$, 1965

2) Spaulding, E.H.: Chemical disinfection and antisepsis in the hospital, J. Hosp, Res., 9: 7-31, 1972

3) Nagao, T.: Sanitization of the hospital facilities-Application to the Bioclean facilities, Japanese Journal of Medical Instrumentation 49:302-307, 1979

4) Masaoka, T. et al: Ozone decontamination of bioclean rooms, Appl. Environ. Microbiol. 43:509513,1982 


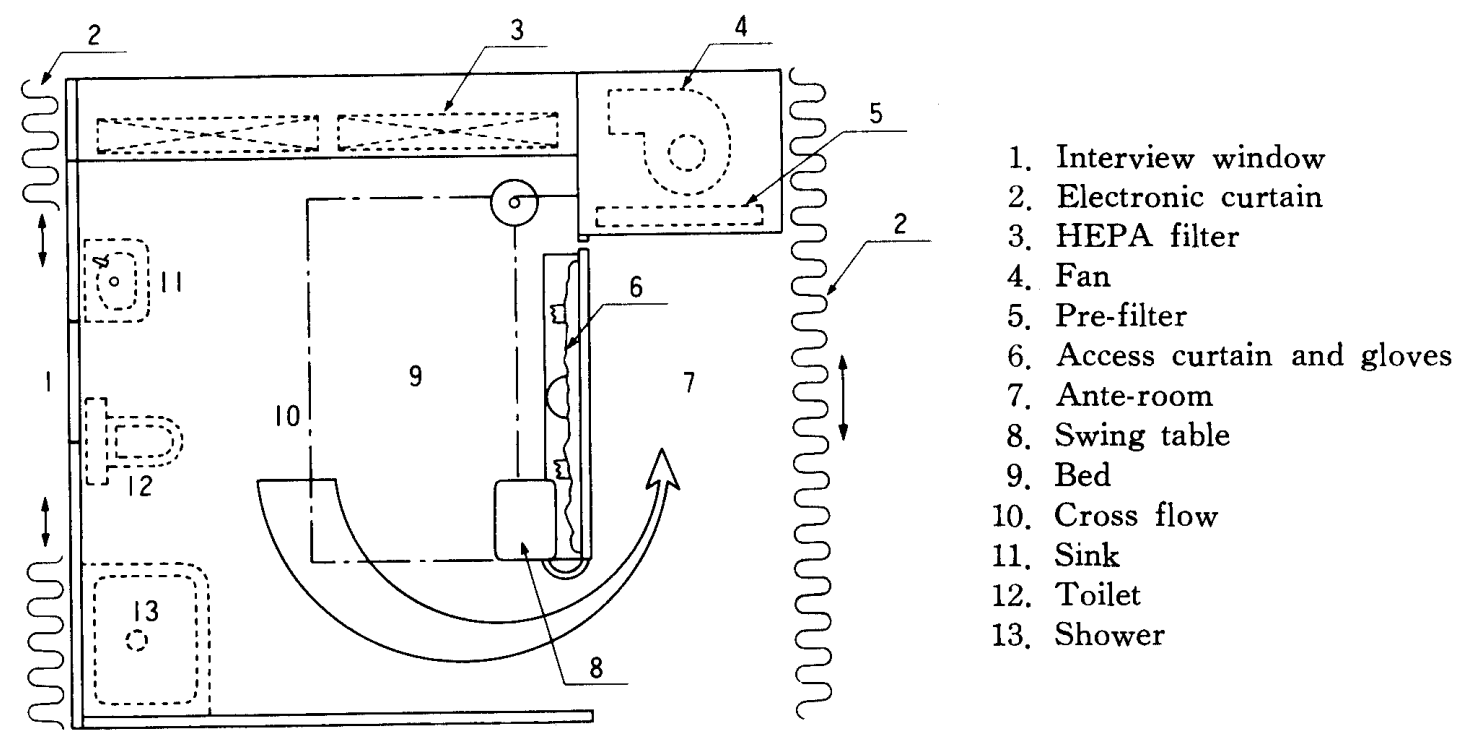

Fig. 1 Cross flow, open-end system

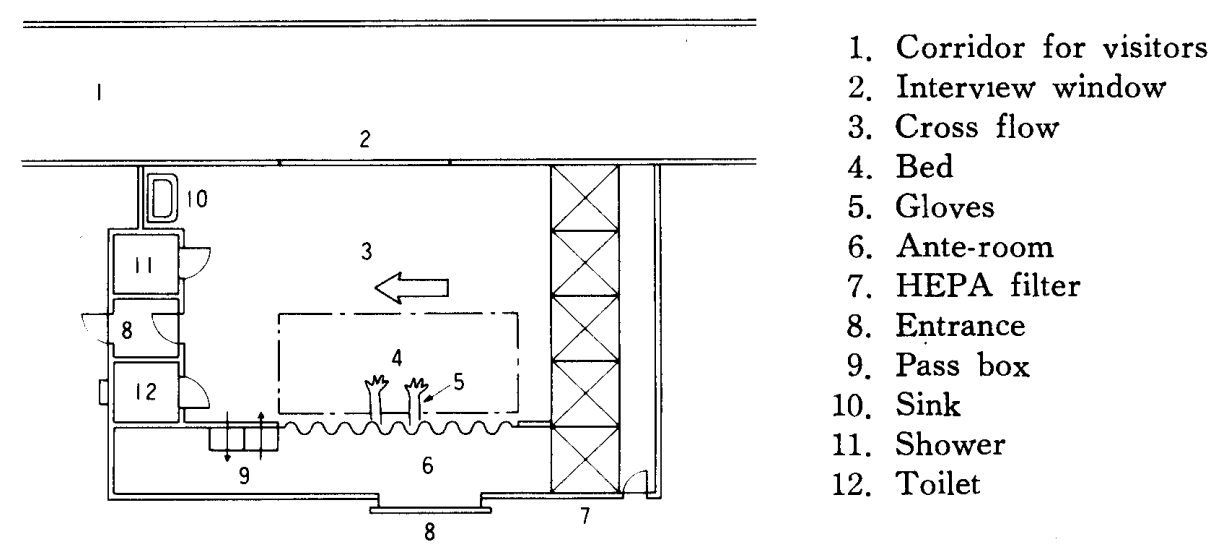

Fig. 2 Cross flow, wall to wall system with the access curtain

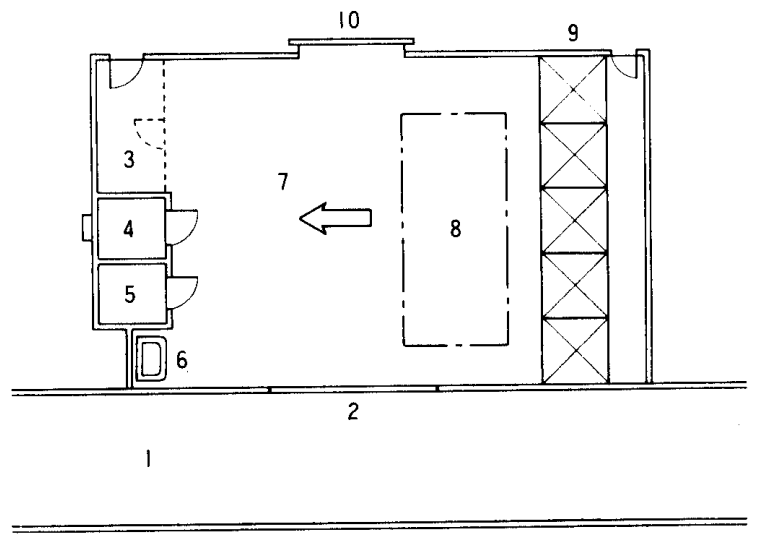

1. Corridor for visitors

2. Interview window

3. Ante-room

4. Toilet

5. Shower

6. Sink

7. Cross flow

8. Bed

9. HEPA filter

10. Entrance

Fig. 3 Cross flow, wall to wall system without the access curtain 


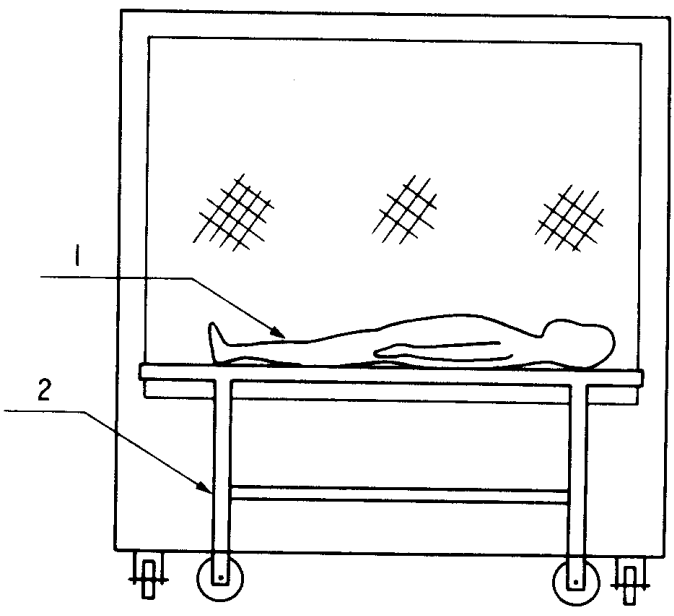

1. Patient

2. Bed

3. Cross flow

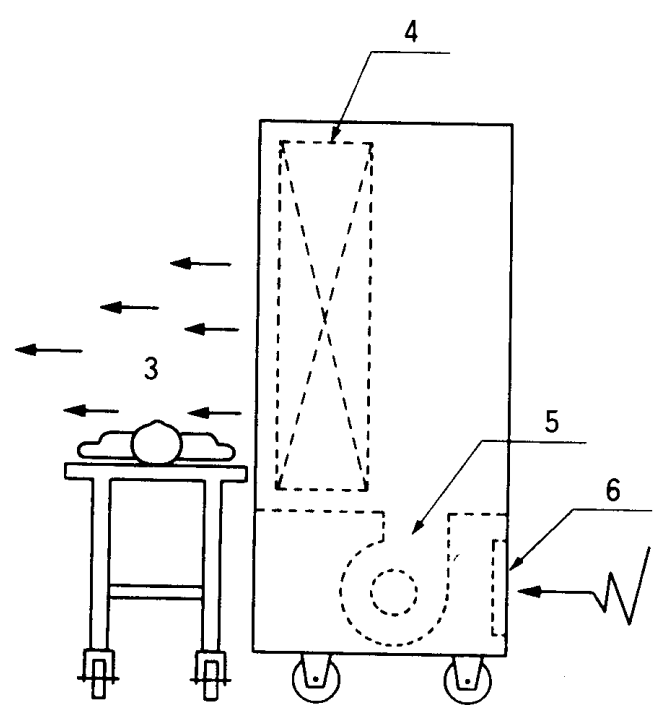

4. HEPA filter

5. Fan

6. Pre-filter

Fig. 4 Clean bench system

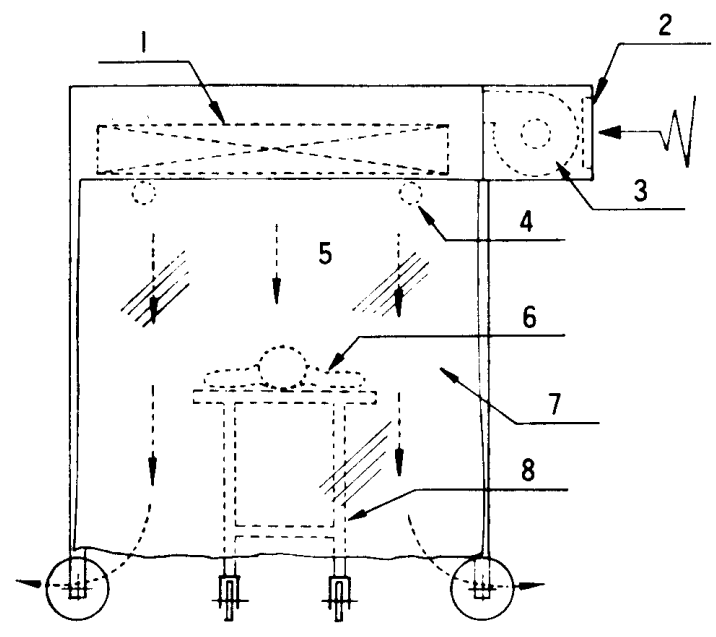

1. HEPA filter

2. Pre-filter

3. Fan

4. Illumination

5. Down flow

6. Patient

7. P. V.C. curtain

8. Bed

Fig. 5 Clean booth system

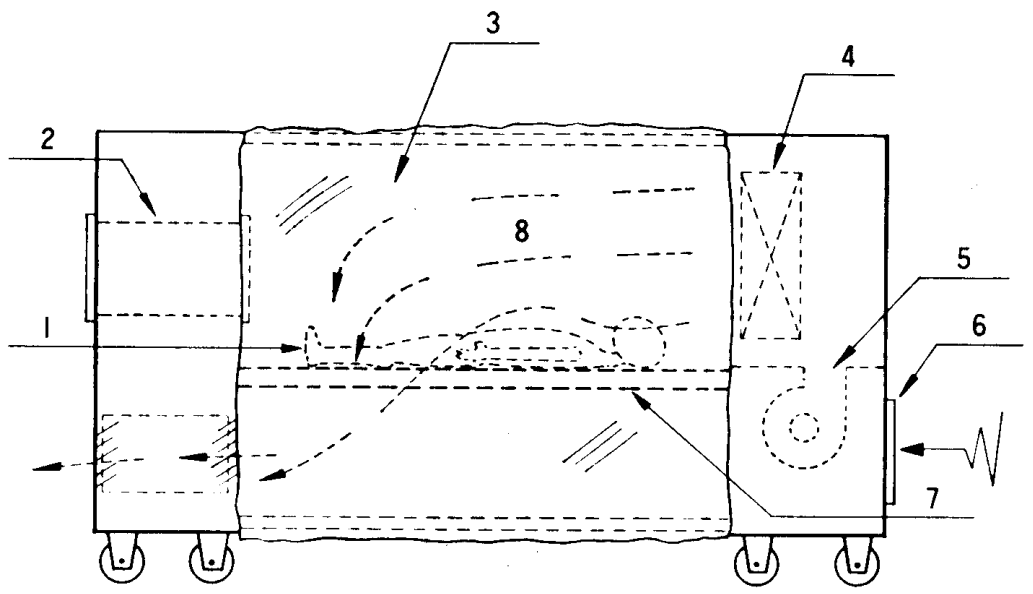

1. Patient

2. Pass box

3. P. V. C. sheet

4. HEPA filter

5. Fan

6. Pre-filter

7. Bed

8. Cross flow

Fig. 6 Plastic isolator system 